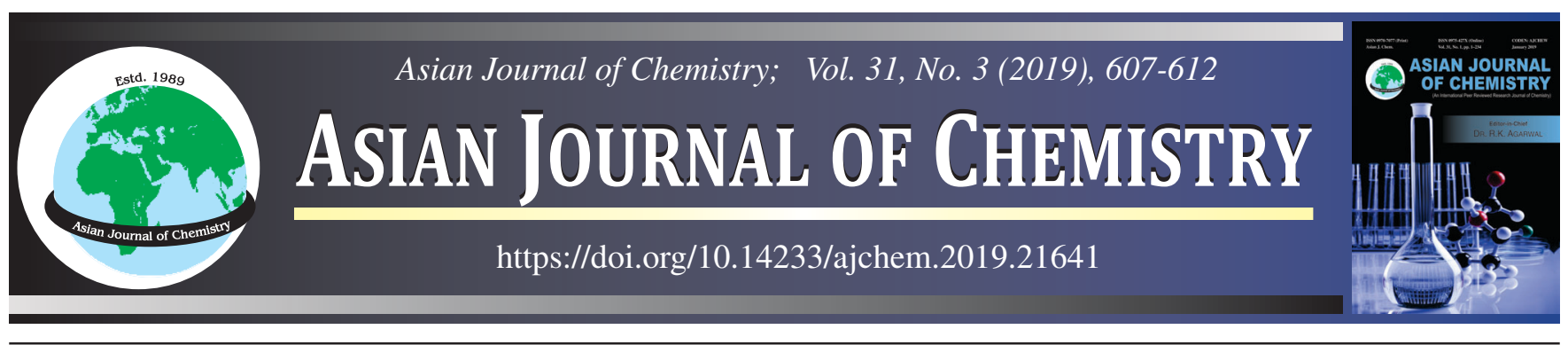

\title{
Synthesis and Structural Investigation of Some Transition Metals Complexes of Benzimidazolium Bromide
}

\author{
Mohammed Mujbel Hasson ${ }^{*}{ }^{\oplus}$, Adil A. Awad ${ }^{\oplus}$ and Mahmoud Najim Al-Jibouri ${ }^{\circledR}$
}

Department of Chemistry, College of Science, Al-Mustansiriyah University, Baghdad, Iraq

*Corresponding author: E-mail: Hassonmm67@uomustansiriyah.edu.iq

\begin{abstract}
The present work involves the synthesis of novel imidazolium salts of bromide in step-wise reactions which are started from preparation of 2,4-dimorpholine-6-(1H-benzimidazole-1-yl)-1,3,5-triazine (1) in potassium hydroxide and DMF solvent followed by substitution reactions with $n$-butyl bromide and $n$-octyl bromide to afford the new ligands names $\mathbf{L}_{1}=1$-(2,4-dimorpholino-1,3,5-triazine-2-yl)-3butyl- $1 H$-benzimidazol-3-ium bromide and $\mathbf{L}_{2}=1$-(2,4-dimorpholino-1,3,5-triazine-2-yl)-3-octyl-1H-benimidazol-3-ium bromide. The new ligands were recrystallized from hot chloroform and the following of reactions completion were carried out by thin layer chromatography (TLC). The formula and structures of the two salts of benzimidazolium bromide were confirmed on the basis of measurements of (CHN) elemental analyses, FT-IR, NMR and EIMS spectroscopy. Furthermore the manganese(II), cobalt(II), nickel(II), copper(II) and zinc(II) complexes were synthesized from the direct reactions of their hydrated metal salts in methanol with the solutions of the ligands in chloroform in 1:1 mole ratio and the analytical data of atomic absorption spectroscopy and elemental analyses revealed the proposed formula of the solid metal complexes. The data obtained from FT-IR, UV-Visible spectra, molar conductivity and magnetic susceptibility measurements confirmed the octahedral environment around cobalt(II) ion in $\left[\mathrm{CoL}\left(\mathrm{H}_{2} \mathrm{O}\right)_{2} \mathrm{Cl}_{2}\right]$ and the tetrahedral geometry was adopted for manganese(II) and zinc(II) ions. However the square-planner structure was expected for the copper(II) and nickel(II) complexes in $\left[\mathrm{MLCl}_{2}\right], \mathrm{M}=\mathrm{Ni}(\mathrm{II})$ and $\mathrm{Cu}$ (II) ions and $\mathrm{L}=\mathrm{L}_{1}$ and $\mathrm{L}_{2}$ ligands. As well as the suitable and favourable active sites in the two ligands $\mathrm{L}_{1}$ and $\mathrm{L}_{2}$ were the two nitrogen atoms of morpholine rings which has been observed from FT-IR spectra and the kinetic stability of five-member ring up on chelation with the metal ions supported the conclusion of the symmetry.
\end{abstract}

Keywords: Transition metal complexes, Benzimidazole, Triazine-imidazole.

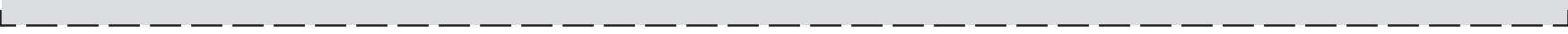

\section{INTRODUCTION}

$1,3,5$-Triazine molecule is called melamine is applied as a part of the assembling of gums [1]. The derivatives of 1,2,3trazine have widely interested many researchers due to their spectrum applications in the fields of herbicides [2], drugs and catalysis in polymers [3-5]. The chelating triazine Lewisbases represent an important class of complex-compound due to their potential to be biologically active and mainly have been known to be antiprotozoals [6-8]. Hoog and co-workers [9] have investigated an-efficient synthesis of a novel class of multidentate polynucleating ligands through the substitution reaction of 2,4,6-trichloro-1,3,5-trazine. As well as the selective amination of cyanuric chloride in presence of 18 -crown- 6 has been prepared with respect of specific reactions that effected by the type of substituent on trazine ring [10]. The neutral binuclear silver(I) complexes with symmetric trazine ligand involving imidazole moiety have reported by Poethig and Strassner [11] and the dimeric structure of $\mathrm{Ag}(\mathrm{I})$ complexes has revealed through the X-ray crystallography. The biological study of triazine derivatives have recently studied via effect on neuronal nicotinic receptors [12] and the results obtained that these derivatives possessed certain kinetic in transport the nicotinic receptors in living cells [13]. However the chelating bis-carbene rhodium(III) complexes have prepared [14] and it's role in the catalysis of imines synthesis has investigated [14]. The medicinal biochemistry of cobalt(II), nickel(II), copper(II) and zinc(II) complexes derived from Schiff base of 1,2,4-trazine derivative have reported by Sing et al. [15] and the identified metal complexes by NMR, FT-IR and UV-visible

This is an open access journal, and articles are distributed under the terms of the Creative Commons Attribution-NonCommercial-ShareAlike 4.0 (CC BY-NC-SA 4.0) International License which allows readers to freely read, download, copy, distribute, print, search, or link to the full texts of its articles and to use them for any other lawful non-commercial purpose as long as the original source is duly acknowledged. 
spectra besides the elemental analyses have exhibited remarkable effects inhibition zones in the antimicrobial studies.

\section{EXPERIMENTAL}

All the reagents and solvents were used as received. NMR spectra were obtained using Bruker Avance AMX 250, 400 spectrometer, mass spectra were obtained in electrospray (ES) mode. The analysis is performed in the laboratories of School of Chemistry of Cardiff University, United Kingdom. Melting points were measured with a Stuart Scientific melting point SMP1 apparatus, magnetic susceptibility measurements were carried out using the Faraday method with (balance magnetic susceptibility model MSB-MKI), molar conductivity $\left(\mathrm{S} \mathrm{cm}^{2}\right.$ $\left.\mathrm{mol}^{-1}\right)$ of the complexes were recorded at $25^{\circ} \mathrm{C}$ for $\left(1 \times 10^{-3}\right.$ M) solution of the samples in a proper solvent (DMF) using a (WTW F561) Weilheim digital supercon, UV-visible spectra of the prepared ligands and complexes were measured in the region (200-800 nm) at $298 \mathrm{~K}$ on (Varain Cary 100 Conc. UVvisible Spectrometer, at the Department of Chemistry, College of Science, university of Mustansiriyah. The vibration spectra were recorded using the (FTIR-600) spectrophotometer in the range (4000-400) $\mathrm{cm}^{-1}$ with their cesium iodide and potassium bromide discs. As well as the structure of the prepared compounds were revealed by elemental analyses (C.H.N.S) on EuroEA-Element Analyzer 3000 at College of Education of Pure Science Ibn-Alhaithum, University of Baghdad. The percent of metals in their solid complexes were measured by flame atomic absorption by using Shimadzu Corporation Model 6809 at Ibn-Sina Center for analytical analysis and quality control.

Synthesis of 2,4-dimorpholine-6-(1H-benzimidazole-1yl)-1,3,5-triazine (1): In a round bottom flask $(100 \mathrm{~mL})$ with condenser $(0.588 \mathrm{~g}, 0.0105 \mathrm{mmol})$ of $\mathrm{KOH}$ was dissolved by (20 mL) DMF, (0.82 g, $7 \mathrm{mmol}$ ) of benzimidazole was added to the solution. The mixture was stirred at ambient temperature for $0.5 \mathrm{~h} \mathrm{(2} \mathrm{g,} 7 \mathrm{mmol})$ of 2,4-dimorpholine-6-chloro-1,3,5triazine was added to the reaction after dissolved with DMF. The reaction was refluxed at $120^{\circ} \mathrm{C}$ for $48 \mathrm{~h}$. After the reaction cooled to room temperature. $100 \mathrm{~mL}$ of water was added, immediately a white precipitate formed. The crude product was filtered then purified by column chromatography (silica, DCM/ $\mathrm{Et}_{2} \mathrm{O}$ 8:2) affording a white solid in yield (80\%).

Synthesis of 1-(2,4-dimorpholino-1,3,5-triazine-2-yl)3-butyl-1 $\boldsymbol{H}$-benzimidazol-3-ium bromide $\left(\mathrm{L}_{1}\right)$ : In around bottom flask provided with condenser $(1.5 \mathrm{~g}, 4.1 \mathrm{mmol})$ of 2,4-dimorpholine-6-( $1 H$-benzimidazole-1-yl)-1,3,5-triazine (1) was dissolved in $(15 \mathrm{~mL}) .(4.9 \mathrm{~g}, 40.1 \mathrm{mmol})$ of 1-bromo butane was added. The mixture was refluxed at $100{ }^{\circ} \mathrm{C}$ for $48 \mathrm{~h}$. After cooling the volume of solution was reduced. Diethyl ether $(30 \mathrm{~mL})$ was added to the residue to produce the crude product as a white solid. The product was recrystallized from $\left(\mathrm{CHCl}_{3} / \mathrm{Et}_{2} \mathrm{O}\right)$ to produce a white solid in yield $(85 \%)$.

Synthesis of 1-(2,4-dimorpholino-1,3,5-triazine-2-yl)3-octyl-1H-benzimidazol-3-ium bromide $\left(\mathbf{L}_{2}\right)$ : In around bottom flask provided with condenser $(1.5 \mathrm{~g}, 4.1 \mathrm{mmol})$ of 2,4-dimorpholine-6-( $1 H$-benzimidazole-1-yl)-1,3,5-triazine (1) was dissolved in $(15 \mathrm{~mL})$. (7.8 g, $40.1 \mathrm{mmol})$ of 1-bromo octane was added. The mixture was refluxed at $100{ }^{\circ} \mathrm{C}$ for 48 h. After cooling the volume of solution was reduced. Diethyl ether $(30 \mathrm{~mL})$ was added to produce the crude product as a white solid. The product was recrystallized by $\left(\mathrm{CHCl}_{3} / \mathrm{Et}_{2} \mathrm{O}\right)$ to produce a white solid (yield $88 \%$ ).

Synthesis of metal complexes: A solution $\mathrm{CuCl}_{2} \cdot 2 \mathrm{H}_{2} \mathrm{O}$ $(0.170 \mathrm{~g}, 1 \mathrm{mmol})$ in $5 \mathrm{~mL}$ of methanol was added to the $(0.480$ $\mathrm{g}, 0.424 \mathrm{~g}, 1 \mathrm{mmol}$ ) of $\left[\mathbf{L}_{1}\right.$ or $\left.\mathbf{L}_{2}\right]$ dissolved in $5 \mathrm{~mL}$ of hot ethanol. The resulted mixture was stirred at (room temperature) till turned the colour of solution into purple then extract with $10 \mathrm{~mol}$ of diethyl ether to afford pale red precipitate of $\mathrm{CuL}_{1}$ complex. The complex.was dried in air and recrystallized from. hot ethanol. The metal complexes of cobalt(II), nickel(II) and zinc(II) were prepared and isolated in the solid state in the same procedure as adopted in copper(II) complexes except that the time of reactions have longed about 1-2 $\mathrm{h}$.

\section{RESULTS AND DISCUSSION}

Analyses and physical measurements: All the complexes are sparingly soluble in common organic solvents but highly soluble in DMF and DMSO. The analytical data (Table-1) indicate that the complexes are mononuclear with 1:1 molar ratio of the benzimidazole ligand to metal ion. The molar conductance in DMSO is in the expected range for their neutral behaviour, indicating that no counter ions are present in the structure of all complexes and supports the formula $\left[\mathrm{MLCl}_{2}\right]$ where $\mathrm{M}$ $=\mathrm{Ni}, \mathrm{Cu}$ and $\mathrm{Zn}(\mathrm{II})$ ions whereas the general formula for cobalt(II) and manganese(II) are $\left[\mathrm{ML}\left(\mathrm{H}_{2} \mathrm{O}\right) \mathrm{Cl}_{2}\right]$. The results obtained from elemental analyses (CHN) and flame atomic absorption spectroscopy were in agreement with the expected data for the structures of free ligands and their metal complexes.

Both of benzimidazolium salts $\left(\mathbf{L}_{1}, \mathbf{L}_{2}\right)$ derived from the triazine have been prepared by two steps. The first step was conducted by the reaction of 2,4-dimorpholine-6-chloro triazine which prepared according of previous literatures [1618] and the benzimidazole in presence of DMF as a solvent at $120{ }^{\circ} \mathrm{C}$ for $48 \mathrm{~h}$. $\mathrm{KOH}$ was used for deprotonation of the benzimidazole before substitution of third chloro atom on triazine [19]. The second step for synthesis the imidazolium salts is the reaction the previous compound with alkyl halides: 1-bromo-butan, 1 -bromo octane at $120^{\circ} \mathrm{C}$ for $48 \mathrm{~h}$. white precipitates were obtained after purified by diffusion method $\left(\mathrm{CHCl}_{3} / \mathrm{Et}_{2} \mathrm{O}\right)$ (Scheme-I).

NMR spectra: The formation of compound 1 was confirmed by ${ }^{1} \mathrm{H}$ NMR and ${ }^{13} \mathrm{C}$ NMR (Table-2). The proton NMR spectrum emerged multiplet peaks in ranges 3.5-3.9 ppm with integration of 16 protons of dimorpholine, which consist with previous literatures [20], in addition singlet peak at $8.9 \mathrm{ppm}$ can be assigned to (NCHN), as well as doublet peaks at 8.3, $7.7 \mathrm{ppm}$ can be attributed to benzimidazole protons $(2 \mathrm{H})$, also multiplet peak was observed at $7.3 \mathrm{ppm}$ with integration $2 \mathrm{H}$ for benzimidazole protons. ${ }^{13} \mathrm{C}$ NMR spectra showed two peaks at $165.11,1.63 .55 \mathrm{ppm}$ corresponding to triazine carbon atoms. As well as two peaks for morpholine carbon atoms were observed at $66.72,43.42 \mathrm{ppm}$. Five peaks in ranges 142.08-115.534 ppm emerged can be assigned to benzimidazole carbon atoms (Table-2). The integrals and chemical shift are consistent with attachment of the benzimidazole group at nitrogen atom.

While ${ }^{1} \mathrm{H}$ NMR spectra for both of imidazoluim salts $\left(\mathbf{L}_{\mathbf{1}}\right.$, $\mathbf{L}_{2}$ ) showed a new peaks at $0.95,1.45,1.97,4.65 \mathrm{ppm}$ with 


\begin{tabular}{|c|c|c|c|c|c|c|c|c|}
\hline \multirow{3}{*}{ Compound } & \multicolumn{7}{|c|}{$\begin{array}{l}\text { TABLE-1 } \\
\text { ANALYTICAL DATA OF LIGANDS }\left(\mathbf{L}_{1}, \mathbf{L}_{2}\right) \text { AND THEIR COMPLEXES }\end{array}$} & \multirow{3}{*}{$\begin{array}{l}\text { Molar conductance } \\
\qquad\left(\mathrm{S} \mathrm{cm}^{2} \mathrm{~mol}^{-1}\right)\end{array}$} \\
\hline & \multirow{2}{*}{$\begin{array}{c}\text { m.f. } \\
\left.\text { (m.w., g mol }{ }^{-1}\right)\end{array}$} & \multirow{2}{*}{ Colour } & \multirow{2}{*}{$\begin{array}{l}\text { Yield } \\
(\%)\end{array}$} & \multicolumn{4}{|c|}{ Elemental analysis (\%): Found (calcd.) } & \\
\hline & & & & $\mathrm{C}$ & $\mathrm{H}$ & $\mathrm{N}$ & $\mathrm{M}$ & \\
\hline $\mathbf{L}_{1}$ & $\begin{array}{l}\mathrm{C}_{22} \mathrm{H}_{30} \mathrm{~N}_{7} \mathrm{O}_{2} \mathrm{Br} \\
\quad(504.43)\end{array}$ & White & 80 & $\begin{array}{c}52.45 \\
(52.38)\end{array}$ & $\begin{array}{c}6,11 \\
(5.99)\end{array}$ & $\begin{array}{c}19.55 \\
(19.44)\end{array}$ & - & 40.5 \\
\hline $\mathbf{L}_{2}$ & $\begin{array}{c}\mathrm{C}_{26} \mathrm{H}_{38} \mathrm{~N}_{7} \mathrm{O}_{2} \mathrm{Br} \\
(560.54)\end{array}$ & White & 85 & $\begin{array}{l}65.25 \\
(64.97)\end{array}$ & $\begin{array}{l}9.36 \\
(8.97)\end{array}$ & $\begin{array}{l}20.65 \\
(20.40)\end{array}$ & - & 35.9 \\
\hline$\left[\mathrm{Cu}\left(\mathbf{L}_{1}\right) \mathrm{Cl}_{2}\right]$ & $\begin{array}{l}\mathrm{C}_{22} \mathrm{H}_{30} \mathrm{~N}_{7} \mathrm{O}_{2} \mathrm{BrCl}_{2} \mathrm{Cu} \\
(638.87)\end{array}$ & Red & 58 & $\begin{array}{c}41.44 \\
(41.36)\end{array}$ & $\begin{array}{c}4.97 \\
(4.73)\end{array}$ & $\begin{array}{l}15.58 \\
(15.35)\end{array}$ & $\begin{array}{l}10.35 \\
(9.95)\end{array}$ & 15.4 \\
\hline$\left[\mathrm{Cu}\left(\mathbf{L}_{2}\right) \mathrm{Cl}_{2}\right]$ & $\begin{array}{l}\mathrm{C}_{26} \mathrm{H}_{38} \mathrm{~N}_{7} \mathrm{O}_{2} \mathrm{BrCl}_{2} \mathrm{Cu} \\
(694.98)\end{array}$ & Red & 65 & $\begin{array}{c}45.28 \\
(44.93)\end{array}$ & $\begin{array}{c}5.85 \\
(5.51)\end{array}$ & $\begin{array}{c}14.95 \\
(14.11)\end{array}$ & $\begin{array}{c}9.65 \\
(9.14)\end{array}$ & 15.7 \\
\hline$\left[\mathrm{Ni}\left(\mathbf{L}_{1}\right) \mathrm{Cl}_{2}\right]$ & $\begin{array}{c}\mathrm{C}_{22} \mathrm{H}_{30} \mathrm{~N}_{7} \mathrm{O}_{2} \mathrm{BrCl}_{2} \mathrm{Ni} \\
(634.02)\end{array}$ & Orange & 55 & $\begin{array}{c}41.85 \\
(41.68)\end{array}$ & $\begin{array}{c}4.95 \\
(4.77)\end{array}$ & $\begin{array}{c}15.77 \\
(15.46)\end{array}$ & $\begin{array}{c}9.68 \\
(9.26)\end{array}$ & 17.9 \\
\hline$\left[\mathrm{Ni}\left(\mathbf{L}_{2}\right) \mathrm{Cl}_{2}\right]$ & $\begin{array}{c}\mathrm{C}_{26} \mathrm{H}_{38} \mathrm{~N}_{7} \mathrm{O}_{2} \mathrm{BrCl}_{2} \mathrm{Ni} \\
(690.13)\end{array}$ & $\begin{array}{c}\text { Dark } \\
\text { brown }\end{array}$ & 65 & $\begin{array}{c}45.55 \\
(45.25)\end{array}$ & $\begin{array}{c}5.97 \\
(5.55)\end{array}$ & $\begin{array}{c}14.77 \\
(14.21)\end{array}$ & $\begin{array}{l}8.95 \\
(8.5)\end{array}$ & 16.4 \\
\hline$\left[\mathrm{Co}\left(\mathbf{L}_{1}\right)\left(\mathrm{H}_{2} \mathrm{O}\right)_{2} \mathrm{Cl}_{2}\right]$ & $\begin{array}{c}\mathrm{C}_{22} \mathrm{H}_{32} \mathrm{~N}_{7} \mathrm{O}_{4} \mathrm{BrCl}_{2} \mathrm{Co} \\
(670.29)\end{array}$ & Dark green & 60 & $\begin{array}{c}40.25 \\
(39.42)\end{array}$ & $\begin{array}{c}5.56 \\
(5.11)\end{array}$ & $\begin{array}{c}14.88 \\
(14.63)\end{array}$ & $\begin{array}{l}9.43 \\
(8.79)\end{array}$ & 18.7 \\
\hline$\left[\mathrm{Co}\left(\mathrm{L}_{2}\right)\left(\mathrm{H}_{2} \mathrm{O}\right)_{2} \mathrm{Cl}_{2}\right]$ & $\begin{array}{c}\mathrm{C}_{26} \mathrm{H}_{42} \mathrm{~N}_{7} \mathrm{O}_{4} \mathrm{BrCl}_{2} \mathrm{Co} \\
(726.40)\end{array}$ & Dark green & 57 & $\begin{array}{c}43.53 \\
(42.99)\end{array}$ & $\begin{array}{c}6.21 \\
(5,83)\end{array}$ & $\begin{array}{c}14.17 \\
(13.50)\end{array}$ & $\begin{array}{c}8.69 \\
(8.11)\end{array}$ & 18.9 \\
\hline$\left[\mathrm{Mn}\left(\mathbf{L}_{1}\right) \mathrm{Cl}_{2}\right]$ & $\begin{array}{c}\mathrm{C}_{22} \mathrm{H}_{30} \mathrm{~N}_{7} \mathrm{O}_{2} \mathrm{BrCl}_{2} \mathrm{Mn} \\
(630.27)\end{array}$ & & 67 & $\begin{array}{c}42.33 \\
(41.93)\end{array}$ & $\begin{array}{c}5.21 \\
(4.80)\end{array}$ & $\begin{array}{c}15.99 \\
(15.56)\end{array}$ & $\begin{array}{c}8.97 \\
(8.72)\end{array}$ & 19.9 \\
\hline$\left[\mathrm{Mn}\left(\mathrm{L}_{2}\right) \mathrm{Cl}_{2}\right]$ & $\begin{array}{c}\mathrm{C}_{26} \mathrm{H}_{38} \mathrm{~N}_{7} \mathrm{O}_{2} \mathrm{BrCl}_{2} \mathrm{Mn} \\
(686.37)\end{array}$ & & 60 & $\begin{array}{c}45.88 \\
(45.50)\end{array}$ & $\begin{array}{c}5.98 \\
(5.58)\end{array}$ & $\begin{array}{c}14.50 \\
(14.28)\end{array}$ & $\begin{array}{c}8.85 \\
(8.00)\end{array}$ & 19.4 \\
\hline$\left[\mathrm{Zn}\left(\mathbf{L}_{1}\right) \mathrm{Cl}_{2}\right]$ & $\begin{array}{c}\mathrm{C}_{22} \mathrm{H}_{30} \mathrm{~N}_{7} \mathrm{O}_{2} \mathrm{BrCl}_{2} \mathrm{Zn} \\
(640.71)\end{array}$ & White & 55 & $\begin{array}{c}41.55 \\
(41.24)\end{array}$ & $\begin{array}{c}4.79 \\
(4.72)\end{array}$ & $\begin{array}{c}15.57 \\
(15.30)\end{array}$ & $\begin{array}{c}10.45 \\
(10.20)\end{array}$ & 17.9 \\
\hline$\left[\mathrm{Zn}\left(\mathbf{L}_{1}\right) \mathrm{Cl}_{2}\right]$ & $\begin{array}{c}\mathrm{C}_{26} \mathrm{H}_{38} \mathrm{~N}_{7} \mathrm{O}_{2} \mathrm{BrCl}_{2} \mathrm{Zn} \\
(696.82) \\
\end{array}$ & White & 59 & $\begin{array}{c}45.23 \\
(44.82) \\
\end{array}$ & $\begin{array}{r}5.90 \\
(5.50) \\
\end{array}$ & $\begin{array}{c}14.78 \\
(14.07) \\
\end{array}$ & $\begin{array}{c}9.98 \\
(9.38) \\
\end{array}$ & 18.5 \\
\hline
\end{tabular}

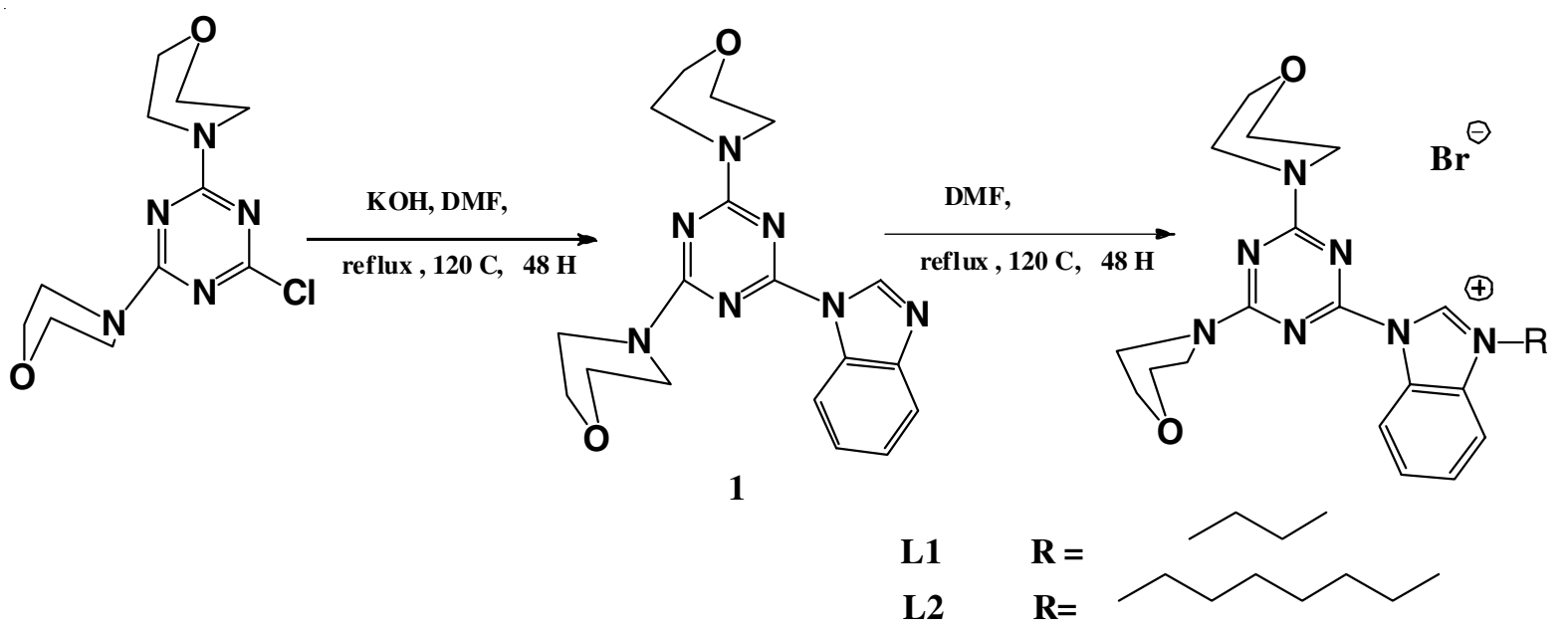

Scheme-I: Synthesis of benzimidazolium salts $\left(\mathbf{L}_{1}, \mathbf{L}_{2}\right)$

TABLE-2

${ }^{1} \mathrm{H}$ NMR AND ${ }^{13} \mathrm{C}$ NMR CHEMICAL SHIFTS (ppm) LIGANDS $\left(\mathbf{L}_{\mathbf{1}}, \mathbf{L}_{\mathbf{2}}\right),\left(400,250, \mathrm{ppm}, \mathrm{DMSO}, \mathrm{CDCl}_{3}\right)$

\begin{tabular}{|c|c|c|c|}
\hline Compd. & m.f. & ${ }^{1} \mathrm{H}$ NMR Chemical shift $\delta_{\mathrm{H}}(\mathrm{ppm})^{*}$ & ${ }^{13} \mathrm{C}$ NMR Chemical shift \\
\hline 1 & $\mathrm{C}_{22} \mathrm{H}_{21} \mathrm{~N}_{7} \mathrm{O}_{2}$ & $\begin{array}{l}3.5-3.9(16 \mathrm{H}, \text { morpholine }), 8.3(\mathrm{~d}, J=2.8,1 \mathrm{H} \text {, } \\
\text { benzimidazole }), 7.7(\mathrm{~d}, J=28,1 \mathrm{H} \text {, benzimidazole }) \text {, } \\
7.3(\mathrm{~m}, 2 \mathrm{H}, \text { benzimidazole }),(\mathrm{s}, 1 \mathrm{H}, \mathrm{NCHN})\end{array}$ & $\begin{array}{l}\text { 165.11, 1.63.55 }(3 \times \mathrm{C}, \text { triazine }), 66.72\left(\left(4 \times \mathrm{c},\left(\mathrm{CH}_{2}\right)_{4},\right.\right. \\
\text { morpholine }), 43.42\left(\mathrm{(} \times \mathrm{c},\left(\mathrm{CH}_{2}\right)_{4}, \text { morpholine }\right), 142.08- \\
115.534(7 \times \mathrm{c} \text {, benzimidazole ring })\end{array}$ \\
\hline $\mathbf{L}_{1}$ & $\mathrm{C}_{22} \mathrm{H}_{30} \mathrm{~N}_{7} \mathrm{O}_{2} \mathrm{Br}$ & $\begin{array}{l}0.95\left(\mathrm{t}, 3 \mathrm{H}, \mathrm{CH}_{3}\right), 1.45\left(\mathrm{~m}, 2 \mathrm{H}, \mathrm{CH}_{2}\right), 1.97(\mathrm{~m}, 2 \mathrm{H}, \\
\left.\mathrm{CH}_{2}\right), 3.7-4.0(\mathrm{br}, 16 \mathrm{H} \text {, morpholine }), 4.65(\mathrm{t}, 2 \mathrm{H}, \\
\left.\mathrm{CH}_{2}-\mathrm{N}\right), 7.35(\mathrm{~m}, 2 \mathrm{H} \text {, benzimidazole }), 8.35(\mathrm{~d}, 1 \mathrm{H}, \\
\text { benzimidazole }), 8.7(\mathrm{~d}, 1 \mathrm{H} \text {, benzimidazole }), 10.25 \\
(\mathrm{~s}, 1 \mathrm{H}, \mathrm{NCHN})\end{array}$ & $\begin{array}{l}13.88\left(1 \times \mathrm{c}, \mathrm{CH}_{3}\right), 19.58\left(1 \times \mathrm{c}, \mathrm{CH}_{2}\right), 31.25\left(1 \times \mathrm{c}, \mathrm{CH}_{2}\right) \text {, } \\
44.38,44.00\left(4 \times \mathrm{c},\left(\mathrm{CH}_{2}\right)_{4}, \text { morpholine }\right), 47.68\left(1 \times \mathrm{c}, \mathrm{CH}_{2}-\mathrm{N}\right) \text {, } \\
66.40,66.19\left(4 \times \mathrm{c},\left(\mathrm{CH}_{2}\right)_{4}, \text { morpholine }\right), 114.64,117.89 \text {, } \\
127.42,128.63,129.23,132.41,143.27(7 \times \mathrm{c}, \text { benzimidazole } \\
\text { ring }), 160.95(1 \times \mathrm{c} \text {, triazine }), 164.27(2 \times \mathrm{c} \text {, triazine })\end{array}$ \\
\hline $\mathbf{L}_{2}$ & $\mathrm{C}_{28} \mathrm{H}_{38} \mathrm{~N}_{7} \mathrm{O}_{2} \mathrm{Br}$ & $\begin{array}{l}0.95\left(\mathrm{t}, 3 \mathrm{H}, \mathrm{CH}_{3}, 1.45\left(\mathrm{~m}, 2 \mathrm{H}, \mathrm{CH}_{2}\right), 2.12(\mathrm{br}, 10 \mathrm{H},\right. \\
\left.\left(\mathrm{CH}_{2}\right)_{5}\right), 3.62-4.12(\mathrm{br}, 16 \mathrm{H} \text {, morpholine }), 4.57(\mathrm{t}, \\
\left.2 \mathrm{H}, \mathrm{CH}_{2}-\mathrm{N}\right), 7.72(\mathrm{~m}, 2 \mathrm{H} \text {, benzimidazole }), 8.25(\mathrm{~d} \text {, } \\
1 \mathrm{H}, \text { benzimidazole }), 8.75(\mathrm{~d}, 1 \mathrm{H} \text {, benzimidazole }), \\
10.25(\mathrm{~s}, 1 \mathrm{H}, \mathrm{NCHN})\end{array}$ & $\begin{array}{l}14.30\left(1 \times \mathrm{c}, \mathrm{CH}_{3}\right), 22.42\left(1 \times \mathrm{c}, \mathrm{CH}_{2}\right), 26.18\left(1 \times \mathrm{c}, \mathrm{CH}_{2}\right) \text {, } \\
28.91\left(1 \times \mathrm{c}, \mathrm{CH}_{2}\right), 29.27\left(1 \times \mathrm{c}, \mathrm{CH}_{2}\right), 31.54\left(1 \times \mathrm{c}, \mathrm{CH}_{2}\right) \text {, } \\
34.54\left(1 \times \mathrm{c}, \mathrm{CH}_{2}\right), 44.38,44.00\left(4 \times \mathrm{c},\left(\mathrm{CH}_{2}\right)_{4} \text {, morpholine }\right) \text {, } \\
47.86\left(1 \times \mathrm{c}, \mathrm{CH}_{2}-\mathrm{N}\right), 66.40,66.19\left(4 \times \mathrm{c},\left(\mathrm{CH}_{2}\right)_{4}, \text { morpholine }\right) \text {, } \\
114.63,117.90,127.42,128.63,129.22,132.38,143.26(7 \times \mathrm{c} \text {, } \\
\text { benzimidazole ring }), 160.95(1 \times \mathrm{c}, \text { triazine }), 164.67(2 \times \mathrm{c} \text {, } \\
\text { triazine }\end{array}$ \\
\hline
\end{tabular}


integration $3 \mathrm{H}, 2 \mathrm{H}, 2 \mathrm{H}, 2 \mathrm{H}$ respectively can be assigned to butyl protons. Some new peaks also observed at $0.95,1.45$, $2.12,4.57$ with integration $3 \mathrm{H}, 2 \mathrm{H}, 10 \mathrm{H}, 2 \mathrm{H}$ for octyl protons, in addition to previous peaks for morpholine and imidazole protons [21].

The formation for both of benzimidazolium salts $\left(\mathbf{L}_{1}, \mathbf{L}_{2}\right)$ confirmed by comparison of their ${ }^{13} \mathrm{C}$ NMR spectra with spectrum of compound (1), new peaks were emerged at 13.88, $19.58,31.25,47.68 \mathrm{ppm}$ can be attributed to butyl carbon atoms for imidazolium salt $\left(\mathbf{L}_{1}\right)$, whereas new peaks at 14.30, 22.42, $26.18,28.91,29.27,31.54,34.54$ and $47.86 \mathrm{ppm}$ to octyl carbon atoms for benzimidazolium salts $\left(\mathbf{L}_{2}\right)$. in addition to previous peaks for morpholine and benzimidazole.

Mass spectra: Mass spectrometry of compound 1 confirmed the attachment of benzimidazole group at nitrogen by the appearance of the peak at (368) can be attributed to the molecular weight of compound $\left[\mathrm{C}_{11} \mathrm{H}_{21} \mathrm{~N}_{7} \mathrm{O}_{2}\right][\mathrm{M}+\mathrm{H}]$.

High resolution mass spectroscopy confirmed the formation of benzimidazolium salt $\left(\mathbf{L}_{1}\right)$ by the appearance of peak at 424.2452 can be assigned to molecular weight of benzimidazolium salt $\left(\mathbf{L}_{1}\right)\left[\mathrm{C}_{22} \mathrm{H}_{30} \mathrm{~N}_{7} \mathrm{O}_{2}\right]^{+}[\mathrm{M}-\mathrm{Br}]^{+}$. While low resolution mass spectrometry for benzimidazolium salt $\left(\mathbf{L}_{2}\right)$ gave peaks at 480.29 can be attributed to molecular weight of salt $\left(\mathbf{L}_{2}\right)$ $\left[\mathrm{C}_{28} \mathrm{H}_{38} \mathrm{~N}_{7} \mathrm{O}_{2}\right]^{+}$[M-Br] $]^{+}$(Figs. 1-3).

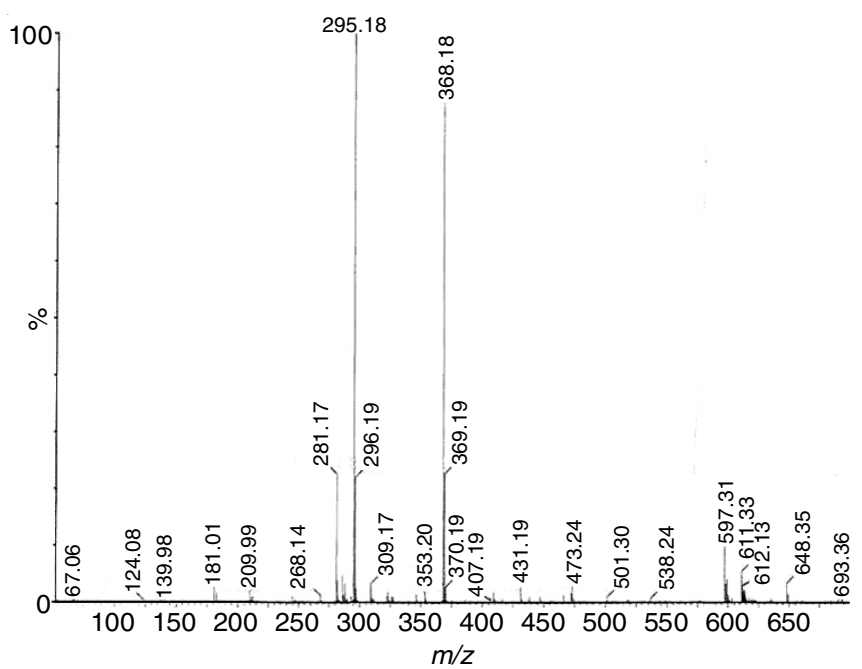

Fig. 1. Mass spectrum of compound 1

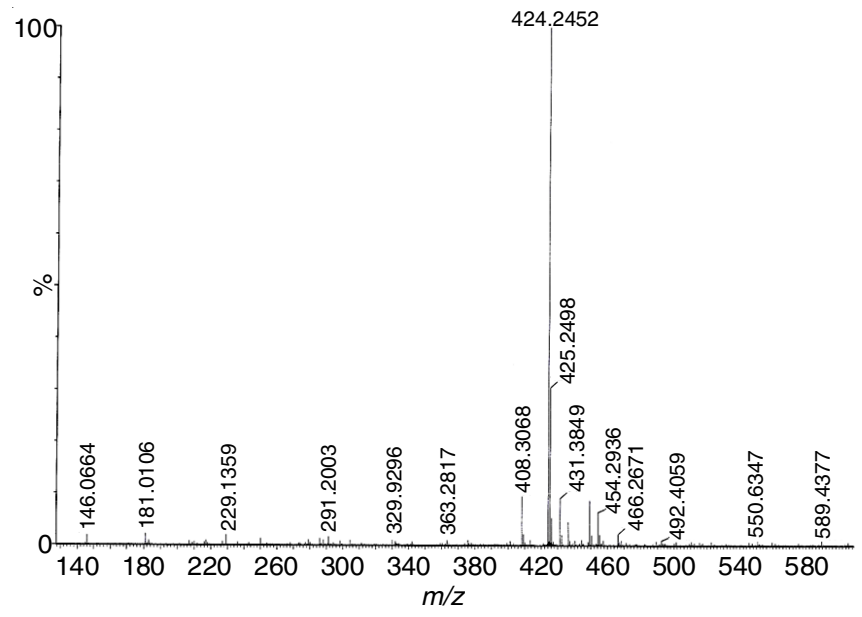

Fig. 2. Mass spectrum of imidazolium salt $\left(\mathbf{L}_{1}\right)$

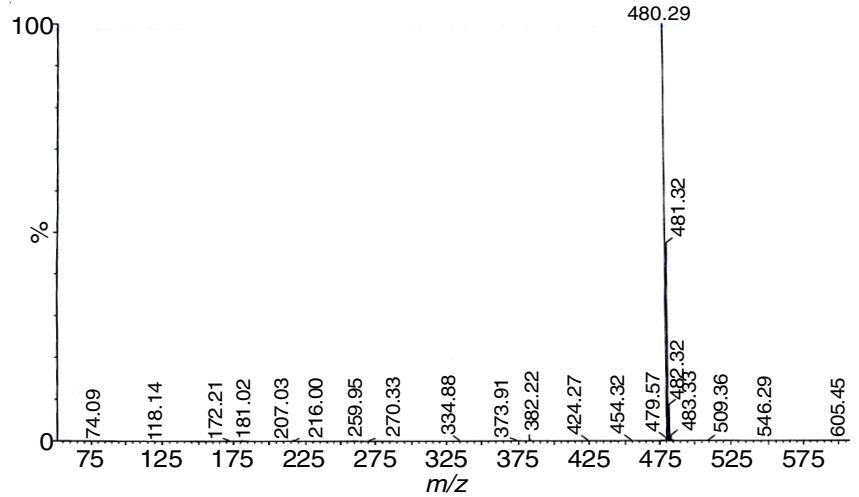

Fig. 3. Mass spectrum of imidazolium salt $\left(\mathbf{L}_{2}\right)$

FTIR spectra of ligands $L_{1}, L_{2}$ and their metal complexes:

The substitution reactions involved on the starting material of trichlorotrazine were the main reaction to enter the morpholine and benzimidazole rings in the step-wise $S N^{2}$ reactions and these products were assigned and identified by the disappearance of $-\mathrm{C}-\mathrm{Cl}$ bond and the new bonds of $-\mathrm{C}-\mathrm{N}$ - around 1390$1300 \mathrm{~cm}^{-1}$ may support the intermediates of bromide salts of imidazole structures $[11,13]$. The IR spectra of imidazoletriazine ligands show the strong absorptions arounds 1616$1566 \mathrm{~cm}^{-1}$ and $1394-1301 \mathrm{~cm}^{-1}$ are assigned to the vibration modes of $-\mathrm{C}=\mathrm{N}$ - and $-\mathrm{C}-\mathrm{N}$ - bonds respectively of triazine and benzimidazole ring [13]. As well as the bands associated with $\mathrm{CH}_{2}$-O-and $-\mathrm{CH}_{2}$ - $\mathrm{N}$-of morpholine ring was observed around 1290-1242 $\mathrm{cm}^{-1}$ confirming the proposed structures of the two synthesized ligands. Furthermore the weak to medium absorptions around $2978-2956 \mathrm{~cm}^{-1}$ clearly belonged to the vibrations of aliphatic -C-H bonds of the long chains of butyl and octyl groups linked to nitrogen atom of benzimidazole moiety $[14,15]$. The comparison of the IR spectra of the ligands with those of their metal complexes, it is noted that the less shifts in the absorptions of the main functional sites of $-\mathrm{C}=\mathrm{N}$ to lower wavenumbers to $1610-1589 \mathrm{~cm}^{-1}$ may be remarkably associated to coordination of the copper(II), nickel(II), cobalt(II) and zinc(II) ions to the nitrogen atom of morpholine and no trazine ring. As well as the changing in the intensity and regions of $-\mathrm{CH}_{2}-\mathrm{N}$ - of morpholine ring supports strongly the binding of this active nitrogen with the empty orbitals of such transition metal ions. However, the weak to medium bands around $458-422 \mathrm{~cm}^{-1}$ and $570-480 \mathrm{~cm}^{-1}$ have ascribed to the coordination bonds of M-N-morpholine respectively. Therefore the results obtained from IR spectra assist in the confirmation of the bidentate behaviour of the two ligands via two nitrogen atoms of morpholine moiety with kinetic stability of six-member chelating ring [22,23]. Furthermore the presence of a broad absorptions around $3500-3400 \mathrm{~cm}^{-1}$ corresponding to the stretching vibration of the - $\mathrm{OH}$ group of hydrated water molecules in manganese(II) and cobalt(II) complexes [14]. As well as the bands occurring around $1280-1236 \mathrm{~cm}^{-1}$ are assigned to the stretching vibration of $\mathrm{C}-\mathrm{N}$ bonds of morpholine rings which have been subjected to lowering in the energy of absorptions up on coordination with the metal ions.

Electronic spectral and magnetic susceptibility: The electronic absorption spectra of the ligands of benzimidazole salts in chloroform show two bands around $250-310 \mathrm{~nm}$ and 233-295 nm with molar extinction coefficients $\varepsilon_{\max }=2.57 \times$ 
$10^{-2}$ to $1.22 \times 10^{-3} \mathrm{M}^{-1} \mathrm{~cm}^{-1}$ ) (Table-3). These bands may be assigned to the ligand field of $-\mathrm{C}=\mathrm{N}$ - and $-\mathrm{C}=\mathrm{C}$ - associated with $\pi-\pi^{*}$ and $n-\pi^{*}$ transitions respectively $[12,13]$. The comparison of the electronic spectra of the ligands solutions with their metal complexes may give strong evidence for the formation of the complexes and support the proposed geometry. The red solution of copper(II) complexes in DMSO exhibited two spin-allowed transitions around (450-480) nm and (390-365)nm assigning to ${ }^{2} \mathrm{~B}_{1 \mathrm{~g}} \rightarrow{ }^{2} \mathrm{~B}_{2 \mathrm{~g}}$ and ${ }^{2} \mathrm{~B}_{1 \mathrm{~g}} \rightarrow{ }^{2} \mathrm{E}_{\mathrm{g}}$ transitions respectively and are consistent with the square-planner geometry of $\mathrm{Cu}$ (II) complexes $[15,16]$. The diamagnetic properties of $\mathrm{Ni}$ (II) complexes confirms the low-spin $3 d^{8}$ configuration and $\left(\mathrm{t}_{2} \mathrm{~g}^{6} \mathrm{eg}^{2}\right)$ according to crystal field model. Therefore the UV-visible spectra would have been in agreement with their expected symmetry as explained below. The orange and dark-brown solutions of nickel(II) complex $\mathrm{Ni}_{1} \mathrm{Cl}_{2}$ in DMSO showed one weak peak at $460 \mathrm{~nm}$ and other high-intense band around $355 \mathrm{~nm}$ which are reasoned from ${ }^{1} \mathrm{~A}_{1 \mathrm{~g}} \rightarrow{ }^{1} \mathrm{~B}_{1 \mathrm{~g}}$ and LMCT respectively and confirms the square-planner environment around $\mathrm{Ni}$ (II) ion. Similarly $\mathrm{Ni}_{2} \mathrm{Cl}_{2}$ complex showed distinct $d$ - $d$ spectra around 510 and $400 \mathrm{~nm}$ which are attributed to the environment of square-planner geometry around $\mathrm{Ni}(\mathrm{II})$ ion. Furthermore the dark green solutions of cobalt(II) complexes in DMSO showed three spin-allowed transitions around (650610), (480-432) and (375-348) nm ascribing to ${ }^{4} \mathrm{~T}_{1 \mathrm{~g}} \rightarrow{ }^{4} \mathrm{~T}_{2 \mathrm{~g}}$, ${ }^{1} \mathrm{~T}_{1 \mathrm{~g}} \rightarrow{ }^{4} \mathrm{~A}_{2 \mathrm{~g}}$ and ${ }^{4} \mathrm{~T}_{1 \mathrm{~g}} \rightarrow{ }^{4} \mathrm{~T}_{1 \mathrm{~g}}(\mathrm{P})$ respectively [18]. The cobalt(II) complexes have magnetic moment values of 4.86 and 4.75 BM, respectively, indicating the presence of three unpaired electrons per metal ion octahedral stereochemistry is suggested [16]. For the nickel(II) complexes, the values are zero BM, respectively denoting the low-spin square-planner complexes of $3 d^{8}$ configurations $\left(\mu_{\mathrm{eff}}=0.00 \mathrm{BM}\right)$. However the spin-only magnetic moments of copper (II) complexes were recorded expected results for spin of one odd electron for $3 d^{9}$ electronic configurations about (1.80-1.90) BM and agrees well with the structures of square-planner geometry. The electronic spectra of manganese(II) complexes in DMSO exhibited two high intense bands around 380-290 $\mathrm{nm}$ and 350-275 $\mathrm{nm}$ assigning to LMCT and ligand field of $-\mathrm{C}=\mathrm{N}$ - and $-\mathrm{C}=\mathrm{C}$ - moiety respectively. As well as the recorded magnetic moments for manganese(II) complexes in the region 5.45-5.80 BM assisting together with UV-visible results assists us in the prediction the tetrahedral geometry around $\mathrm{Mn}(\mathrm{II})$ ion [18]. The white-off solutions of zinc(II) complexes displayed strong bands around 300-285 $\mathrm{nm}$ which are associated with $\mathrm{Cl}-\mathrm{Zn}^{2+}$ and $\pi-\pi *$ transitions respectively. The mainly $d$ - $d$ spectra and ligand to metal charge transfer bands for the solutions of the synthesized complexes in continuous with their magnetic moments revealed that copper(II) and nickel(II) complexes were square-planner whereas the cobalt(II) was octahedral and Mn(II), Zn(II) complexes were suggested as tetrahedral geometry (Fig. 4).

\section{ACKNOWLEDGEMENTS}

The authors are thankful to the Department of Chemistry, College of Science, Mustansiriyah University for providing laboratory for facilities to the service laboratory for providing spectra and analytical magnetic susceptibility measurements. Authors are also grateful to the Cardiff University for carring out the NMR and El-MS spectra for intermediates and ligands.

\section{CONFLICT OF INTEREST}

The authors declare that there is no conflict of interests regarding the publication of this article.

TABLE-3

ELECTRONIC SPECTRAL DATA, MAGNETIC MOMENTS OF LIGANDS ( $\mathrm{L}_{1}$ AND $\mathrm{L}_{2}$ ) AND ITS METAL COMPLEXES

\begin{tabular}{|c|c|c|c|c|c|}
\hline Compound & $\lambda_{\max }(\mathrm{nm})$ & $v\left(\mathrm{~cm}^{-1}\right)$ & Assignment & $\mu_{\text {eff }}$ (B.M.) & Geometry \\
\hline \multirow[t]{2}{*}{$\mathbf{L}_{1}$} & 250 & 40000 & $\mathrm{n}-\pi^{*}$ & - & - \\
\hline & 310 & 32258 & $\pi-\pi^{*}$ & & \\
\hline \multirow[t]{2}{*}{$\mathbf{L}_{2}$} & 233 & 42918 & $\mathrm{n}-\pi^{*}$ & - & - \\
\hline & 295 & 33898 & $\pi-\pi^{*}$ & & \\
\hline \multirow[t]{2}{*}[\mathrm{Cu}(\mathbf{L}_{1})\mathrm{Cl}_{2}]{} & 450 & 22222 & ${ }^{2} \mathrm{~B}_{1 \mathrm{~g}} \rightarrow{ }^{2} \mathrm{~B}_{2 \mathrm{~g}}$ & 1.8 & Square planner \\
\hline & 390 & 25641 & ${ }^{2} \mathrm{~B}_{1 \mathrm{~g}} \rightarrow{ }^{2} \mathrm{E}_{\mathrm{g}}$ & & \\
\hline \multirow[t]{2}{*}[\mathrm{Cu}(\mathbf{L}_{2})\mathrm{Cl}_{2}]{} & 450 & 22222 & ${ }^{2} \mathrm{~B}_{1 \mathrm{~g}} \rightarrow{ }^{2} \mathrm{~B}_{2 g}$ & 1.9 & Square planner \\
\hline & 390 & 25641 & ${ }^{2} \mathrm{~B}_{1 \mathrm{~g}} \rightarrow{ }^{2} \mathrm{E}_{\mathrm{g}}$ & & \\
\hline \multirow[t]{2}{*}[\mathrm{Ni}(\mathbf{L}_{1})\mathrm{Cl}_{2}]{} & 460 & 21739 & ${ }^{1} \mathrm{~A}_{1 \mathrm{~g}} \rightarrow{ }^{1} \mathrm{~B}_{1 \mathrm{~g}}$ & 0.00 & Square planner \\
\hline & 355 & 28169 & LMCT & & \\
\hline \multirow[t]{2}{*}[\mathrm{Ni}(\mathbf{L}_{2})\mathrm{Cl}_{2}]{} & 510 & 19607 & ${ }^{1} \mathrm{~A}_{1 \mathrm{~g}} \rightarrow{ }^{1} \mathrm{~B}_{1 \mathrm{~g}}$ & 0.00 & Square planner \\
\hline & 400 & 25000 & LMCT & & \\
\hline \multirow[t]{3}{*}[\mathrm{Co}(\mathbf{L}_{\mathbf{1}})(\mathrm{H}_{2}\mathrm{O})_{2}\mathrm{Cl}_{2}]{} & 650 & 15384 & ${ }^{4} \mathrm{~T}_{1 \mathrm{~g}} \rightarrow{ }^{4} \mathrm{~T}_{2 \mathrm{~g}}$ & 4.86 & Octahedral \\
\hline & 480 & 20833 & ${ }^{1} \mathrm{~T}_{1 \mathrm{~g}} \rightarrow{ }^{4} \mathrm{~A}_{2 \mathrm{~g}}$ & & \\
\hline & 375 & 26666 & ${ }^{4} \mathrm{~T}_{1 \mathrm{~g}} \rightarrow{ }^{4} \mathrm{~T}_{1 \mathrm{~g}}(\mathrm{P})$ & & \\
\hline \multirow[t]{3}{*}[\mathrm{Co}(\mathbf{L}_{2})(\mathrm{H}_{2}\mathrm{O})_{2}\mathrm{Cl}_{2}]{} & 610 & 16393 & ${ }^{4} \mathrm{~T}_{1 \mathrm{~g}} \rightarrow{ }^{4} \mathrm{~T}_{2 \mathrm{~g}}$ & 4.75 & Octahedral \\
\hline & 432 & 23148 & ${ }^{1} \mathrm{~T}_{1 \mathrm{~g}} \rightarrow{ }^{4} \mathrm{~A}_{2 g}$ & & \\
\hline & 348 & 28734 & ${ }^{4} \mathrm{~T}_{1 \mathrm{~g}} \rightarrow{ }^{4} \mathrm{~T}_{1 \mathrm{~g}}(\mathrm{P})$ & & \\
\hline \multirow[t]{2}{*}[\mathrm{Mn}(\mathbf{L}_{\mathbf{1}})\mathrm{Cl}_{2}]{} & 290 & 34482 & $\pi-\pi^{*}$ & 5.45 & Tetrahedral \\
\hline & 380 & 26315 & LMCT & & \\
\hline \multirow[t]{2}{*}[\mathrm{Mn}(\mathbf{L}_{2})\mathrm{Cl}_{2}]{} & 275 & 36363 & Ligand field & 5.80 & Tetrahedral \\
\hline & 350 & 28571 & LMCT & & \\
\hline$\left[\mathrm{Zn}\left(\mathbf{L}_{\mathbf{1}}\right) \mathrm{Cl}_{2}\right]$ & 300 & 33333 & $\pi-\pi^{*}$ & 0.00 & Tetrahedral \\
\hline \multirow[t]{2}{*}[\mathrm{Zn}(\mathbf{L}_{1})\mathrm{Cl}_{2}]{} & 285 & 35714 & $\pi-\pi^{*}$ & 0.00 & Tetrahedral \\
\hline & 360 & 27777 & LMCT & & \\
\hline
\end{tabular}




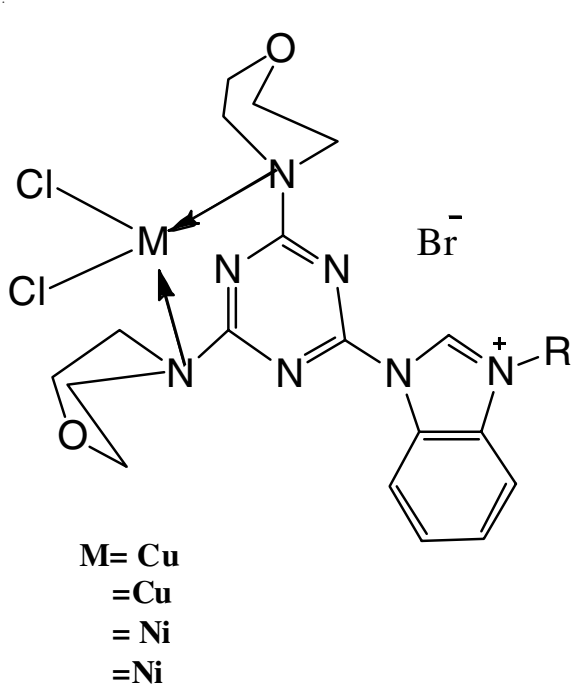

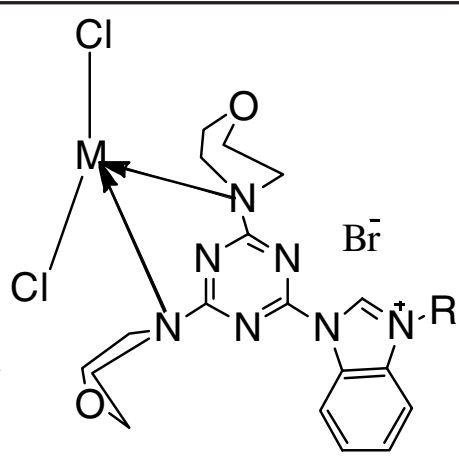

$\begin{aligned} \mathbf{M} & =\mathbf{M n} \\ & =\mathbf{M n} \\ & =\mathbf{Z n} \\ & =\mathbf{Z n}\end{aligned}$

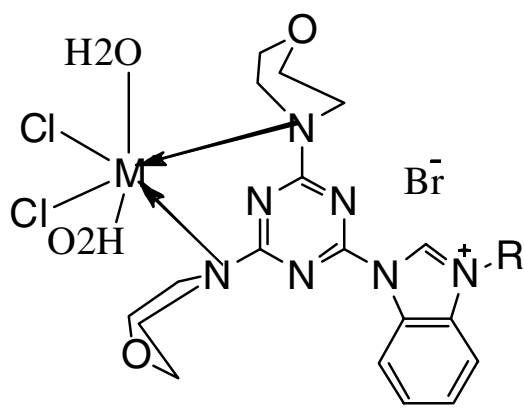

$\mathrm{M}=\mathbf{C o}$

$=\mathbf{C o}$

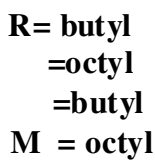

Fig. 4. Proposed structures of synthesized complexes

\section{REFERENCES}

1. V.K. Pandey, S. Tusi, Z. Tusi, M. Joshi and S. Bajpai, Acta Pharm., 54, 1 (2004);

https://doi.org/10.1002/chin.200417155.

2. M. Garmouna, H. Blanchoud, M.-J. Teil, M. Blanchard and M. Chevreuil, Water Air Soil Poll., 132, 1 (2001); https://doi.org/10.1023/a:1012017025060.

3. B. Klenke, M. Stewart, M.P. Barrett, R. Brun and I.H. Gilbert, J. Med. Chem., 44, 3440 (2001); https://doi.org/10.1021/jm010854+.

4. H.S. Patel and V.C. Patel, Eur. Polym. J., 37, 2263 (2001); https://doi.org/10.1016/s0014-3057(01)00107-0.

5. V.L. Rusinov, I.N. Egorov, O.N. Chupakhin, E.F. Belanov, N.I. Bormotov and O.A. Serova, Pharm. Chem. J., 45, 655 (2012); https://doi.org/10.1007/s11094-012-0698-z.

6. D.K. Basedia, B.K. Dubey and B. Shrivastava, Am. J. PharmTech Res., 1, 174 (2011).

7. K. Sztanke, K. Pasternak, J. Rzymowska, M. Sztanke and M. KandeferSzerszen, Eur. J. Med. Chem., 43, 1085 (2008); https://doi.org/10.1002/chin.200840166.

8. J. Spychala, D.W. Boykin, W.D. Wilson, M. Zhao, R.R. Tidwell, C.C. Dykstra, J.E. Hall, S.K. Jones and R.F. Schinazi, Eur. J. Med. Chem., 29, 363 (1994);

https://doi.org/10.1016/0223-5234(94)90061-2.

9. P. Hoog, P. Gamez, W.L. Driessen and J. Reedijk, Tetrahedron Lett., 43, 6783 (2002); https://doi.org/10.1016/s0040-4039(02)01498-3.

10. S. Samaritani, P. Peluso, C. Malanga and R. Menicagli, Eur. J. Org. Chem., 1551 (2002); https://doi.org/10.1002/1099-0690(200205)2002:9\%3C1551::aid-ejoc 1551\%3E3.0.co;2-y.

11. A. Poethig and T. Strassner, Organometallics, 30, 6674 (2011); https://doi.org/10.1021/om200860y.
12. R. Hurst, H. Rollema and D. Bertrand, Pharmacol. Therap., 137, 22 (2013); https://doi.org/10.1016/j.pharmthera.2012.08.012.

13. A. Vazquez-Romero, M. Criado, A. Messeguer, M. Vidal-Mosquera, J. Mulet, F. Sala and S. Sala, ACS Chem. Neurosci., 5, 683 (2014); https://doi.org/10.1021/cn5000748.

14. M. Albrecht, R. H. Crabtree, J. Matab and E. Peris, Chem. Commun., 32 (2002); https://doi.org/10.1039/b109491b

15. K. Singh, M.S. Barwa and P. Tyagi, Eur. J. Med. Chem., 42, 394 (2007); https://doi.org/10.1039/b109491b

16. J.T. Thurston, J.R. Dudley, D.W. Kaiser, I. Hechenbleikner, F.C. Schaefer and D. Holem-Hansen, J. Am. Chem. Soc., 73, 2981 (1951); https://doi.org/10.1021/ja01151a001.

17. V.B. Kurteva and Carlos A. M. Afonso, Green Chem., 6,183 (2004); https://doi.org/10.1039/b313689b.

18. A.M. Venkatesan, C.M. dehnhardt, E.D. Santos, Z. Cheng, O.D. Santons, S. Kaloustian, G. Khafizovas, N. Brooijmans, R. Mallon, I. Hollander and L. Feldberg, J. Med. Chem., 53, 3169 (2010); https://doi.org/10.1021/jm901783v.

19. T. Matsuno, M. Kato, Y. Tsuchida, M. Takahshi, S. Yaguchi and S. Terada, Chem. Pharm. Bull., 45, 291 (1997); https://doi.org/10.1248/cpb.45.291.

20. F. Almalioti, J. Macdougall, S. Hughes, M.M. Hasson, R. Jenkins, B.D. Ward, G.J. Tizzard, S.J. Coles, D.W. Williams, S. Bamford, I.A. Fallis and A. Dervisi, Dalton Trans., 42, 12370 (2013); https://doi.org/10.1039/c3dt51400e.

21. N. Gonsior, F. Mohr, and H. Ritter, Beilstein. J. Org. Chem., 8, 390 (2012); https://doi.org/10.3762/bjoc.8.42.

22. R.M. Silverstein, F. Webster, D.J. Kienle,Spectrometric Identification of Organic Compounds, John Wiley \& Sons: New York (1963). https://doi.org/10.1002/ange.19650771675.

23. K. Nakamoto, Infrared and Raman Spectra of Inorganic and Coordination Compounds, Wiley Interscience: New York (1997); https://doi.org/10.1366/0003702981943761. 